\title{
ARTIKELEN
}

\section{Kaderstellen en controleren door de gemeenteraad: een zware opgave}

\author{
Klaartje Peters \& Peter Castenmiller
}

\begin{abstract}
Gezien de toenemende betekenis van het lokaal bestuur en het gemeentelijk takenpakket is het van belang om te weten of gemeenteraden erin slagen het bestuur goed te controleren. Dat is een van de hoofdtaken die bij de invoering van het dualisme bij de gemeenteraad is belegd. Raadsleden zijn zich bewust van het belang van de controlerende taak, maar over de manier waarop ze deze invullen, is weinig bekend. Onderzoek in tien gemeenten naar het gebruik van het beschikbare instrumentarium voor kaderstelling en controle laat zien dat gemeenteraden sommige instrumenten weinig of niet gebruiken, met name op het punt van informatieverwerving en de ondersteuning van de raad. Goede informatievoorziening aan de raad blijkt soms ondergeschikt te worden gemaakt aan het politieke belang van de coalitie. En overal worstelen raadsleden met het bij de dualisering ingevoerde instrumentarium van programmabegroting en -rekening: dat biedt onvoldoende mogelijkheden voor kaderstelling en controle. Bij gebrek aan een helder toetsingskader is niet vast te stellen of dit afbreuk doet aan de effectiviteit van controle en kaderstelling. Wat goede of effectieve controle is en waartoe deze dient, blijkt ook geen onderwerp van gesprek in de lokale arena.
\end{abstract}

Relevantie voor practitioners. Dit artikel laat zien dat: (a) raadsleden meer en beter gebruik kunnen maken van beschikbare instrumenten voor kaderstelling en controle en de mogelijkheden voor ondersteuning van de raad; (b) het instrument van de programmabegroting (en programmarekening) de verwachtingen van de dualisering niet lijkt waar te maken; (c) burgemeesters, als voorzitter van de raad, zich niet altijd verantwoordelijk voelen voor een goede informatievoorziening van de raad en in bredere zin het beter positioneren van de raad als kaderstellend en controlerend orgaan. Hier is meer leiderschap vereist.

\section{Kaderstelling en controle in de lokale praktijk}

De invoering van het dualisme in het lokaal bestuur in 2002 had tot doel om de verhoudingen tussen raad en college meer in balans te brengen. De basis daarvoor werd gevonden in het streven naar meer duidelijkheid in deze verhoudingen: het college bestuurt en voert het beleid uit, de raad stelt de kaders en controleert het bestuur; meebesturen door de raad was nadrukkelijk niet meer de bedoeling. De raad werd toegerust met verschillende nieuwe instrumenten, om zo beter invulling te kunnen geven aan zijn verantwoordelijkheden. Op advies van de Staats- 
commissie Dualisme en lokale democratie werd niet getornd aan het primaat van de gemeenteraad, maar nieuw was wel de expliciete benoeming van de twee hoofdtaken (naast de volksvertegenwoordigende rol) van de gemeenteraad, te weten kaderstelling en controle.

Wat weten we over de wijze waarop gemeenteraden invulling geven aan deze hoofdtaken? Die vraag is actueel en urgent. Met de recente sterke groei van taken van gemeenten, met name vanwege de decentralisaties in het sociaal domein, is de behoefte aan inzicht in prestaties en besteding van middelen door gemeenten navenant toegenomen. De laatste tijd zien we steeds meer gemeenten en gemeenteraden die worden overvallen door grote financiële tekorten in het sociaal domein. Inwoners, belangenorganisaties en raadsleden vragen zich af of gemeenten in de uitvoering van het beleid voldoende kwaliteit kunnen garanderen. De twijfels worden niet alleen gevoed door een almaar groeiend takenpakket en daarmee toenemende verantwoordelijkheden van het gemeentebestuur. In recente rapporten (Commissie-Van de Donk, 2016; Commissie-Ollongren, 2016) is vastgesteld dat de verhoudingen tussen raad en college nog steeds aandacht behoeven, dat positie en taakuitoefening van de raad aan versterking toe is, en dat de raad beter moet worden ondersteund en toegerust om zijn taken uit te kunnen voeren. In het representatieve stelsel op lokaal niveau is de gemeenteraad immers het voornaamste controleorgaan. Dat maakt de vraag naar het functioneren van raden van groot belang.

Genoemde zorgen over de mogelijkheden van raadsleden om een goede invulling te geven aan hun kaderstellende en controlerende taken waren voor het Ministerie van BZK aanleiding om begin 2018 een onderzoek te entameren. ${ }^{1}$ In dit artikel wordt daarvan verslag gedaan. Centrale vraag was hoe het wettelijk beschikbare instrumentarium, zoals dat bij de invoering van het dualisme tot stand kwam, wordt gebruikt, en of er aanleiding is om dat instrumentarium te heroverwegen en aan te vullen. De vraag bestaat uit twee delen. Het eerste deel is een beschrijvende vraag, gericht op de praktijk van het gebruik van de beschikbare instrumenten. Het tweede deel vraagt om een oordeel over die praktijk, op basis waarvan aanleiding kan zijn om de inrichting van het instrumentarium te heroverwegen. Die laatste vraag is nadrukkelijk opgevat als een bredere vraag naar de effectiviteit van de kaderstelling en controle in het lokaal bestuur.

\section{Eerder onderzoek}

Uit onderzoek dat de Staatscommissie Dualisme en lokale democratie aan het eind van de vorige eeuw liet verrichten naar de toenmalige rol- en taakvervulling door de actoren in het lokaal bestuur, blijkt dat er vóór de invoering van het dua-

1 Het onderzoek werd uitgevoerd in opdracht van het Ministerie van Binnenlandse Zaken en Koninkrijksrelaties. Tijdens het onderzoek kon worden geprofiteerd van een breed samengestelde klankbordgroep, bestaande uit een raadslid, een burgemeester, griffiers, een vertegenwoordiger van de Nederlandse Vereniging voor Raadsleden en van de VNG, een bestuursjurist, plus enkele vertegenwoordigers van het Ministerie van BZK. 
lisme veel lippendienst werd bewezen aan de leidende rol van de gemeenteraad. De bestuurspraktijk was echter een andere. De raad delegeerde op grote schaal bestuursbevoegdheden aan het college, terwijl daar vaak niet of nauwelijks voorwaarden aan werden verbonden (Denters e.a., 2000). De Staatscommissie constateerde verder dat de volksvertegenwoordigende (agenderende) en de controlerende rol van de raad onvoldoende uit de verf kwamen. Zo werden de beschikbare controle-instrumenten relatief weinig gebruikt. De verklaring daarvoor lag in het monistisch ideaal:

'Vanuit het formele model, waarin het college wordt gezien als een "eerste commissie" uit de raad, is er geen reden om zwaarwegende controle-instrumenten van de raad jegens de wethouders in het leven te roepen. Het regelgevende en bestuurlijke primaat van de raad zouden immers meer dan voldoende moeten zijn en alle waarborgen in zich dragen om de wethouders in hun afgeleide rol te houden.' (Staatscommissie, 2000: 60)

Uit het onderzoek onder raadsleden bleek dat zij veel waarde hechtten aan die controlerende rol, maar volgens de commissie was dit in tegenspraak met 'de praktijk waarin dit in veel gemeenten van veel minder betekenis blijkt te zijn' (Bakker e.a., 2000: 103).

De vraag is wat er met de invoering van het dualisme is veranderd in de wijze waarop raadsleden kaders stellen en het college controleren. De evaluatie van de Wet dualisering gemeentebestuur van 2004 kwam wat te vroeg voor conclusies over de beoogde effecten van de wet, dat wil zeggen de versterking van de kaderstellende en controlerende rol van de raad (Berenschot, 2004: 20-21). Uit de evaluatie blijkt dat raadsleden in de jaren na de invoering van de wet actiever gebruikmaakten van het instrumentarium voor kaderstelling en controle (2004: 61), en er meer over kaderstelling werd gesproken. Versterking van beide rollen had volgens betrokken actoren in het lokaal bestuur (nog) niet plaatsgevonden (2004: 128-137). Wel constateerden de onderzoekers in 2004 dat na invoering van het dualisme wethouders vaker aan de voltallige raad of in de raadscommissie verantwoording aflegden (2004: 133-136). Berenschot wees er verder op dat er in gemeenten veel onduidelijkheid bestond over de vraag wat kaderstelling behelst en wat een goede invulling is (2004: 128-132). Enkele jaren later concludeerde De Groot (2009) op basis van surveyonderzoek voor en na de dualisering dat de herinrichting van het lokaal bestuur ertoe had geleid dat raadsleden meer belang waren gaan hechten aan hun controlerende rol. In het gedrag van raadsleden was echter geen verandering opgetreden (De Groot, 2009: 183-184).

Over het feitelijk gebruik van het raadsinstrumentarium sinds 2002 weten we weinig. In 2008 inventariseerde B\&A Groep in opdracht van het Ministerie van BZK het gebruik van enkele kaderstellende en controlerende instrumenten. Voor sommige instrumenten leverde dat weinig op, zoals het zeer beperkte gebruik van interpellaties en - nog minder - van het enquêterecht in Nederlandse gemeenten; als er al gebruik van werd gemaakt, was dat in de grotere gemeenten. Andere 
instrumenten, zoals raadsvragen, werden wel in alle gemeenten gebruikt (B\&A Groep, 2008: 23-24). De onderzoekers lieten zich niet uit over de effectiviteit van die instrumenten. B\&A noemde in deze studie de informatievoorziening aan raden door de colleges een van de 'hardnekkige kwesties' in het lokaal bestuur, en constateerde, op basis van een analyse van lokale rapporten en notities, dat de kwaliteit van de door het college aan de raad verstrekte informatie tekortschoot. Tegelijkertijd werd gerapporteerd dat ongeveer zestig procent van de raadsleden het eens was met de stelling dat de raad voldoende actief door het college wordt geïnformeerd; ongeveer een even groot deel van de raadsleden vond dat de raad voldoende actief door de burgemeester wordt geïnformeerd (B\&A Groep, 2008: 12-13). In een recent proefschrift constateert de jurist en burgemeester Hessels (2018) dat gemeenteraden beter dan nu het geval is gebruik zouden kunnen maken van de raadsinstrumenten ambtelijke bijstand en fractievergoedingen. Dit zou volgens hem kunnen leiden tot een minder zware belasting voor raadsleden en een betere invulling van hun kaderstellende en controlerende taak.

Dat informatievoorziening een 'hardnekkige kwestie' is in het lokaal bestuur, bleek ook uit verkennend onderzoek naar de praktijk van informatievoorziening aan gemeenteraden uit 2013 (Castenmiller e.a., 2013). Het onderzoek liet zien dat er alle reden is om aan te nemen dat er op lokaal niveau net als in politiek Den Haag nogal wat mankeert aan die informatievoorziening (Enthoven, 2011). Maar het beoordelen ervan stuit op moeilijkheden. Informatievoorziening is uiterst politiek - 'kennis is macht' -, en objectieve maatstaven voor goede informatievoorziening ontbreken. In de praktijk blijkt dat raadsleden binnen een en dezelfde gemeenteraad zeer verschillend oordelen over de wijze waarop ze door het bestuur worden geïnformeerd. In het rapport werd vastgesteld dat (politieke) cultuur een sterk bepalende factor is voor de grote verschillen in tevredenheid tussen gemeenten. Verder blijkt dat er op lokaal niveau geen natuurlijke 'eigenaar' is van goede informatievoorziening, dit in tegenstelling tot de Tweede Kamer, waar de Kamervoorzitter (met ondersteuning) opkomt voor de belangen van de volksvertegenwoordiging. Recent onderzoek van de VNG (2019: 18-22) laat zien dat raadsleden meer ondersteuning van de griffie nodig zeggen te hebben om een goede informatiepositie ten opzichte van het college te verkrijgen.

De laatste jaren krijgt het thema van controle door de gemeenteraad wat meer aandacht van bestuurskundigen (Denters e.a., 2017; Schram e.a., 2017; Denters, 2016). Deze publicaties zijn veelal gericht op het bijdragen aan versterking van de controlerende taak van de raad, onder meer door het in beeld brengen van vernieuwende manieren van controle en verantwoording, al dan niet samen met burgers en andere (maatschappelijke) partijen. Uit de publicaties blijkt dat raadsleden het moeilijk hebben met hun controlerende taak. Dat het ook daadwerkelijk niet goed gaat, wordt wel gesuggereerd maar blijft enigszins impliciet.

Voor één aspect van het controlerende werk van gemeenteraden in het bijzonder is veel aandacht geweest de afgelopen jaren. Een steeds terugkerende constatering in enquêtes onder raadsleden en landelijke en lokale onderzoeksrapporten is dat raadsleden uiterst ontevreden zijn over de controlemogelijkheden die zij heb- 
ben ten aanzien van het groeiend aantal regionale samenwerkingsverbanden (Boogers \& Reussing, 2018; Nederlandse Vereniging voor Raadsleden, 2017; Boogers e.a., 2016; Raad voor het openbaar bestuur, 2015; Daadkracht, 2014 en 2017). Empirisch onderzoek op casusniveau, met name door lokale rekenkamers, ${ }^{2}$ laat zien dat de indirecte sturings- en controlerelatie, de groeiende complexiteit en de moeizame informatievoorziening het voor veel raadsleden moeilijk maken om voldoende controle uit te oefenen op de taken die op regionaal niveau worden uitgevoerd. In het onderzoek waarover in dit artikel verslag wordt gedaan, is er bewust voor gekozen deze regionale controle buiten beschouwing te laten, omdat het een specifiek aspect van de controle door gemeenteraden betreft waarvoor, zoals gezegd, al veel aandacht is.

Samenvattend kan worden gesteld dat het op basis van het beschikbare onderzoek niet goed mogelijk is om uitspraken te doen over de effectiviteit van de kaderstelling en controle door gemeenteraden. Sinds de dualisering begin deze eeuw is er wel meer aandacht voor deze beide taken van de gemeenteraad. Duidelijk is verder dat er zorgen zijn over de informatievoorziening aan raden, en over de wijze waarop gemeenteraden hun kaderstellende en controlerende taak vervullen, met name ten aanzien van de groeiende bovenlokale taakuitoefening.

\section{Analysekader}

\section{Kernbegrippen}

In de meeste beschikbare onderzoeken en beschouwingen over positie en functioneren van gemeenteraden wordt opmerkelijk weinig aandacht besteed aan de vraag wat controle is en waartoe het dient. In de (internationale) academische literatuur wordt veel gebruikgemaakt van termen zoals scrutiny, overview, oversight en monitoring, en van het verwante begrip accountability (verantwoording), ${ }^{3}$ wat bijdraagt aan de conceptuele onduidelijkheid. Ook de wetgever verschaft hierover geen duidelijkheid. Het woord controle(ren) komt in de Gemeentewet alleen voor in relatie tot financieel beleid en financiële controle, in wetsartikelen zoals die over de rekenkamer, de accountant en de begroting en jaarrekening. ${ }^{4}$ In de memorie van toelichting bij de Wet dualisering gemeentebestuur wordt weliswaar veel over de versterking van de controlerende functie van de raad gesproken, maar het is niet duidelijk wat de wetgever bedoelt of beoogt met die (versterkte) controle. Het meest in de buurt komt de volgende formulering: 'Een deel van de

2 Ten behoeve van dit artikel is geen systematische analyse gemaakt. Enkele voorbeelden zijn: Rekenkamers Rijk van Nijmegen (2017), Grip krijgen op Veilig Thuis; Rekenkamer Den Haag (2016), Moeite met afstand; Rekenkamer Breda (2015), Verbonden partijen en de rol van de raad. Een onderzoek naar de informatievoorziening, sturing en beheersing ten aanzien van verbonden partijen in Breda.

3 Sommigen beschouwen controle als een onderdeel of activiteit van verantwoordingsprocessen (De Groot, 2009: 45-46; De Groot e.a., 2010: 405). Of zoals de commissie-Elzinga het uitdrukt: 'Zo beschouwd, staat de controlerende taak van de raad in belangrijke mate in het teken van openbare publieke verantwoording' (Staatscommissie-Elzinga, 2000: 256).

4 Art. 182, 813, 186, 212 en 213 Gemeentewet. 
controle zal erin bestaan na te gaan of het college met inachtneming van de door de raad gestelde regels, zijn bevoegdheden goed heeft gebruikt' (Kamerstukken II 2000/01, 27751, nr. 3, p. 26).

Wij gaan ervan uit dat controle van het college door de gemeenteraad zich op méér moet richten dan het (goed) gebruik van bevoegdheden. In onze studie definiëren wij controle als de vergelijking van de feitelijke situatie met een norm. Controle door de gemeenteraad is erop gericht na te gaan of het gevoerde bestuur in overeenstemming is met de gestelde normen, ofwel kaders. ${ }^{5}$ In de memorie van toelichting bij de Wet dualisering gemeentebestuur worden twee soorten kaders onderscheiden:

1 kaderstelling door middel van regelgeving (verordeningen) en budgetrecht (begroting): door middel van regels en geld kan de raad zijn wensen afdwingen;

2 kaderstelling door middel van politiek-bestuurlijke instrumenten, zoals de vaststelling van beleidsnota's of moties.

Een ander onderscheid dat kan worden gemaakt, betreft enerzijds beleidsinhoudelijke of politieke kaders en anderzijds financiële (verslagleggings)kaders. Dat leidt tot twee verschillende vormen van controle: politieke controle en financiële controle (vgl. Van der Woude, 2011). Dit is geen strikt onderscheid, in die zin dat financiële kaders een vertaling vormen van beleidsinhoudelijke of politieke doelstellingen. Maar het onderscheid leidt wel tot een andersoortige controle: politieke controle richt zich op de doeltreffendheid en doelmatigheid, terwijl financiële controle met name gericht is op de rechtmatigheid: zijn bevoegdheden gerespecteerd en is de verslaglegging in overeenstemming met de werkelijkheid? ${ }^{6}$ Het onderscheid is in de praktijk van gemeenteraden herkenbaar, in die zin dat de tweede vorm vaak afzonderlijk is belegd, bij de accountant en in de auditcommissie.

\section{Informatievoorziening en controle}

De meeste publicaties over controle in het openbaar bestuur (zie o.m. Schram e.a., 2017; Denters, 2016; De Groot, 2009; B\&A Groep, 2008; Bovens e.a., 2008) komen vroeg of laat te spreken over informatievoorziening door het bestuur aan de volksvertegenwoordiging. De (grond)wettelijke plicht voor het bestuur om de volksvertegenwoordiging van de noodzakelijke informatie te voorzien is immers bedoeld om controle mogelijk te maken: om te kunnen vergelijken met de normen of kaders is informatie nodig over de feitelijke situatie. Dat zien we terug in de wet: in de Grondwet het cruciale artikel 68 over de inlichtingenplicht van ministers en staatssecretarissen, en in de Gemeentewet de artikelen 169 lid 2 en 180 lid 2, met de passieve en de actieve informatieplicht voor college en burgemeester. Bestuurders moeten niet alleen alle gevraagde informatie verstrekken, maar

5 We blijven hier dicht bij De Groot, die het controleren van het gemeentebestuur omschrijft als: 'gather information on their performance and evaluate it accordingly' (De Groot, 2009: 45-46).

6 In de praktijk wordt financiële controle veelal breder ingevuld dan louter een toets op de rechtmatigheid. Ook dan komen vragen naar de doelmatigheid en doeltreffendheid aan de orde. 
ook op eigen initiatief alle informatie geven 'die de raad voor de uitoefening van zijn taak nodig heeft'. Vanwege de nauwe band tussen informatievoorziening en controle schaart de Staatscommissie Dualisme en lokale democratie (commissieElzinga) instrumenten voor informatieverwerving onder het controle-instrumentarium (Staatscommissie-Elzinga, 2000: 251). Wij hebben ervoor gekozen om deze lijn te volgen.

\section{Beoordeling van controlepraktijk}

De onderzoeksvraag of een aanpassing of aanvulling van het controle-instrumentarium nodig is, vereist een oordeel over de praktijk van kaderstelling en controle door gemeenteraden. Hoe kan anders worden bepaald of het bestaande instrumentarium naar behoren functioneert? De vraag is waar een dergelijk oordeel op kan worden gebaseerd. De wetgever maakt niet duidelijk wat kaderstelling en controle behelzen of moeten behelzen. De literatuur bevat nauwelijks elementen voor een geschikt beoordelingskader: wat is effectieve of goede controle? Toch is die vraag voor de gemeentelijke praktijk een cruciale vraag: niet alleen worstelen gemeenteraden en individuele raadsleden zoals gezegd met hun rol, maar goede controle draagt ook bij aan de kwaliteit van het bestuur en zijn prestaties.

In navolging van Denters (2016) hebben we voor aanvang van het onderzoek ingezet op toepassing van het analytisch kader van Bovens e.a. (2008). Zij onderscheiden drie hoofdfuncties of -motieven van verantwoording, en gebruiken die om de kwaliteit van verantwoordingsarrangementen te kunnen beoordelen ('Is it doing its job?'):

- Verantwoording afleggen is een bijdrage aan de democratische legitimatie van bestuurlijk handelen door dit handelen te verbinden met de voorkeuren van burgers of hun gekozen vertegenwoordigers. Goede verantwoording stelt burgers of hun vertegenwoordigers in staat om het bestuurlijk handelen te monitoren en te evalueren, én brengt bestuurders ertoe te handelen in overeenstemming met de voorkeuren van de burgers of hun vertegenwoordigers.

- Vanuit het gezichtspunt van de rechtsstaat is het van belang dat machtsconcentratie bij niet-democratisch gelegitimeerde functionarissen wordt voorkomen en dat er effectieve tegenmacht wordt georganiseerd. Goede verantwoording vermindert of voorkomt machtsmisbruik, corruptie en willekeur, en bevordert de integriteit van het bestuur.

- In de derde plaats kan verantwoording bijdragen aan een beter presterende overheid (prestatiestaat) door feedback en kritische reflectie. Goede verantwoording draagt bij aan het lerend vermogen van publieke organisaties.

Het bleek echter niet goed mogelijk de driedeling in dit onderzoek te gebruiken voor de beoordeling van de effectiviteit van de controle. Allereerst was het inventariseren van het gebruik van het omvangrijke beschikbare raadsinstrumentarium in de praktijk een lastige en arbeidsintensieve klus. In paragraaf 4 wordt dit nader toegelicht. Bovendien bood deze inventarisatie geen goede basis voor de toetsing van het analytisch kader. Een dergelijke toetsing zou om andersoortige gegevens hebben gevraagd dan de verzamelde gegevens over raadsinstrumenten en de inzet 
daarvan in de gemeentelijke praktijk. Besloten is om de driedeling slechts te gebruiken (testen) in de gesprekken met raadsleden, met de vraag of deze in de praktijk van hun controlerende werk wordt herkend. Dat zou een basis kunnen vormen voor eventueel vervolgonderzoek.

Om toch een antwoord te formuleren op het tweede deel van de onderzoeksvraag naar de wenselijkheid van aanpassing of aanvulling van het instrumentarium, is ervoor gekozen om de wenselijkheid in de ogen van de betrokken actoren te onderzoeken. Deze vraag is in de gesprekken aan de orde gesteld (zie paragraaf 4).

\section{Aanpak van het onderzoek}

Een belangrijk uitgangspunt van het onderzoek was om nadrukkelijk aandacht te besteden aan de lokale context waarbinnen invulling wordt gegeven aan het daadwerkelijk gebruik van de diverse beschikbare instrumenten. Doel was ook dat gebruik te plaatsen in het bredere perspectief van de kaderstellende en controlerende taak van de raad. Om die reden is niet gekozen voor grootschalig surveyonderzoek, zoals eerder wel is gedaan door Berenschot (2004), B\&A Groep (2008), De Groot (2009) en De Groot e.a. (2010).

Gezien dit uitgangspunt is het onderzoek geconcentreerd in een beperkt aantal (tien) gemeenten. ${ }^{7}$ Een keuze voor tien gemeenten heeft onvermijdelijk een toevallig karakter. Om een al te eenzijdige samenstelling van het aantal te onderzoeken gemeenten te voorkomen, is wel gezorgd voor spreiding naar gemeentegrootte en over het land. ${ }^{8}$

De onderzoeksaanpak voor elke gemeente is steeds gelijk geweest. In de eerste fase zijn de lokale afspraken en procedures voor de inzet van het instrumentarium voor kaderstelling en controle in kaart gebracht en is op basis van het raadsinformatiesysteem, verslagen van raads- en commissievergaderingen en andere documentatie (zoals griffiejaarverslagen) het daadwerkelijk gebruik van de instrumenten geïnventariseerd. Dit bleek onverwacht lastig en veel werk te zijn. Veel van de onderzochte gemeenten bleken niet te beschikken over adequate overzichten, en reconstructie van het gebruik stuitte nogal eens op een gebrek aan toegankelijke informatie. Voor de meeste instrumenten is het gebruik in het jaar 2017 in kaart gebracht; voor enkele weinig gebruikte instrumenten is naar de volledige vorige raadsperiode (2014-2018) gekeken.

In de tweede fase zijn deze gegevens (in de vorm van een checklist voor de interviewers) gebruikt als basis voor een reeks gesprekken met raadsleden en andere relevante actoren in de geselecteerde gemeenten. In deze gesprekken is nader

7 Het betrof de gemeenten Almere, Borne, Groningen, Heerenveen, Nijmegen, Rijswijk, Steenbergen, Uitgeest, Venlo en Zeist.

8 In navolging van vergelijkbare onderzoeken (onder meer B\&A Groep, 2008) is gekozen voor een evenwichtige verdeling over drie categorieën gemeenten $(<25.000$ inwoners, 25.000-75.000 inwoners, > 75.000), waarbij in de grootste categorie ook twee grote steden zaten. Daarnaast is gezorgd voor een spreiding over tien van de twaalf provincies. 
ingegaan op de wijze waarop de instrumenten door de raad in die gemeente worden gebruikt om invulling te geven aan zijn kaderstellende en controlerende taken, en de rol die de andere actoren daarbij spelen. In de gesprekken is verder consequent gevraagd hoe respondenten oordelen over die invulling, en of aanpassing of aanvulling van het instrumentarium in hun ogen nodig is.

De samenstelling van de uiteindelijke groep gesprekspartners verschilde licht van gemeente tot gemeente. In alle gemeenten is gesproken met (oud-)raadsleden, de griffier, de (concern)controller en de burgemeester. In de meeste gemeenten is gesproken met één of meer wethouders, ${ }^{9}$ de gemeentesecretaris ${ }^{10}$ en één of meer andere medewerkers die een rol hebben in het verkeer met de gemeenteraad, zoals bestuursassistenten of bestuursadviseurs. Gezien de specifieke aandacht voor de invulling van de controlerende taak is ook in alle gemeenten gesproken met vertegenwoordigers van de rekenkamer(commissie). Wat de gesprekken met (oud-)raadsleden betreft zijn er per gemeente verschillen ontstaan, variërend van twee tot acht gesprekspartners. De ene keer vonden de gesprekken met elk (oud-)raadslid apart plaats, de andere keer was er sprake van een groepsgesprek. Het beperkte aantal gesprekspartners uit de raad, maar ook de setting van groepsgesprekken, moet als een beperking van het onderzoek worden beschouwd.

In het onderzoek is gestreefd naar een algemeen beeld van de praktijk van kaderstelling en controle in gemeenten, en uitdrukkelijk niet naar een beoordeling van de praktijk in elk van de tien afzonderlijke gemeenten. Los van het feit dat daarvoor (nog) geen duidelijk beoordelingskader beschikbaar was, zou dat zonder twijfel problemen hebben opgeleverd qua medewerking aan het onderzoek. De onderzochte gemeenten en de betrokken actoren hebben meegewerkt op voorwaarde dat hun gemeente niet herkenbaar zou zijn in het rapport. ${ }^{11}$

\section{Bevindingen: kaderstelling door gemeenteraden}

Uit het onderzoek blijkt dat kaderstelling door de raad een vrij passief karakter heeft. Het bevestigt de stelling van Van Ostaaijen dat het college in de praktijk vaak het voortouw neemt en de kaders formuleert, en de raad alleen maar ja of nee hoeft te zeggen (Van Ostaaijen, 2018: 37; Van Ostaaijen, 2016: 17-18). De raad neemt af en toe amendementen aan op collegevoorstellen (waaronder de begroting) en stuurt soms zelf met een motie of een initiatiefvoorstel. Dat laatste

9 Een voor het onderzoek verstorende factor was dat de interviews plaatsvonden voor en vlak na de zomer van 2018. In het merendeel van de geselecteerde gemeenten hadden in maart 2018 gemeenteraadsverkiezingen plaatsgevonden. Niet alleen leidde dat tot veranderingen in de personele samenstelling van het college van B\&W en de raad, het had ook zijn effecten op de beschikbaarheid en bereidheid van wethouders (en soms ook raadsleden) om een gesprek aan te gaan. In één gemeente is geen wethouder gesproken.

10 In één gemeente is niet met de gemeentesecretaris gesproken, maar wel met de controller en het hoofd bestuursondersteuning.

11 Om die reden is er ook voor gekozen om geen getalsmatige uitkomsten te presenteren, in de trant van: 'In twee van de tien gemeenten worden nooit mondelinge vragen gesteld.' 
instrument wordt het minst gebruikt door raden: in geen van de onderzochte gemeenten meer dan twee per jaar. De meest genoemde verklaring hiervoor is het arbeidsintensieve karakter van het opstellen van een initiatiefvoorstel: dat schrikt raadsleden af. Amendementen komen iets vaker voor, variërend van 2 tot 38 amendementen per jaar. In de meeste gemeenten is het een gebruikelijk instrument bij de begrotingsbehandeling, en in iets mindere mate bij de besluitvorming over verordeningen en beleidsnota's. Deze bevindingen komen overeen met die uit de evaluatie van de dualisering van 2008 (B\&A Groep, 2008), waaruit ook bleek dat er beperkt gebruik wordt gemaakt van deze beide instrumenten. Het voorbereiden van moties is het minste werk en het lijkt niet toevallig dat dit kaderstellende instrument wat meer wordt gebruikt: in de onderzochte gemeenten werden in 2017 per gemeente tussen de 16 en de 106 moties ingediend.

Het belangrijkste kaderstellende document in het lokaal bestuur is zonder twijfel de begroting. In alle onderzochte gemeenten wordt de begroting voor het daaropvolgende jaar in het najaar door de raad behandeld en vastgesteld, op basis van de door het college van B\&W voorbereide conceptbegroting. Raadsleden worden in de gelegenheid gesteld hierover vragen te stellen, onder meer door technische vragenrondes (schriftelijk), en soms ook door informatieavonden of 'spreekuren' met betrokken ambtenaren. De daadwerkelijke behandeling van de begroting in de raad gaat in het algemeen gepaard met algemene beschouwingen, in de vorm van uitgebreide mondelinge bijdragen van fractievoorzitters en reacties van het college, de indiening van moties en amendementen en een politiek debat, en wordt afgerond met een stemming over de begroting. Een verandering die in veel van de onderzochte gemeenten geleidelijk heeft plaatsgevonden in de afgelopen jaren, is dat het moment van financieel vooruitblikken van de begrotingsbehandeling verschuift van het najaar naar een moment eerder in het jaar, bij de behandeling van de Kadernota (soms Voorjaarsnota, Zomernota of Perspectiefnota genoemd) vóór het zomerreces. Steeds vaker gaat de behandeling van dat document gepaard met een vorm van algemene beschouwingen door de raadsfracties.

Het onderzoek laat zien dat in alle gemeenteraden in de onderzochte gemeenten door raadsleden in meer of mindere mate wordt getwijfeld aan de mogelijkheden die de programmabegroting hun biedt om daadwerkelijk te sturen door middel van duidelijke kaderstelling. ${ }^{12}$ Ook diverse griffiers, bestuurders en ambtenaren (controllers) zien dat raadsleden vaak onvoldoende uit de voeten kunnen met de begroting als sturingsinstrument. Om die reden wordt (of is recentelijk) in bijna alle gemeenten gesleuteld aan de opzet en inrichting van de programmabegro-

12 Met de dualisering zijn de comptabiliteitsvoorschriften voor gemeenten aangepast, zoals de commissie-Elzinga ook had aanbevolen. Het Besluit Begroting Verantwoording provincies en gemeenten (BBV) stelt eisen aan de begroting en de jaarrekening en aansluiting daartussen. Sinds de dualisering kent de begroting behalve een financieel deel ook verplicht een 'programmaplan', waarin voor de onderscheiden programma's doelstelling en uitvoering moeten zijn aangegeven. Doel was de inzichtelijkheid en informatieve waarde van beide documenten te versterken, om zo de sturing en ook de controle en verantwoording door de raad te verbeteren. 
ting, vaak in overleg met de auditcommissie of een hiervoor ingestelde raadswerkgroep, soms met ambtelijke ondersteuning. De ingrepen richten zich veelal op de programma-indeling van de begroting. Ook de selectie van de gebruikte indicatoren is onderwerp van discussie, in sommige gemeenten bijna permanent; de toevoeging met ingang van begrotingsjaar 2017 van een aantal verplichte (beleids)indicatoren op grond van het Besluit Begroting en Verantwoording (BBV) heeft hier niets aan veranderd.

Deze constateringen over de bruikbaarheid van de programmabegroting sluiten naadloos aan bij de onderzoeken die lokale rekenkamers in de afgelopen jaren overal in het land hebben gedaan naar het instrument programmabegroting en de relatie met de jaarrekening. ${ }^{13}$ Zonder uitzondering stellen rekenkamers in deze onderzoeken vast dat de doelstellingen in de programma's te globaal zijn geformuleerd, onvoldoende bruikbare indicatoren zijn onderscheiden en weinig verband wordt gelegd tussen de doelstellingen en de ingezette middelen. Dit heeft tot gevolg dat de raad er onvoldoende mee kan sturen. Ook een landelijke adviescommissie stelde in 2014 vast dat de aanleiding voor de instelling van de commissie was gelegen in de wens om de kaderstellende en controlerende rol van de raad te versterken door 'meer en gemakkelijker inzicht in begroting en verantwoording' (Adviescommissie Vernieuwing van de begroting en verantwoording van gemeenten, 2014: 7). De ervaren financieel columnist van het blad Binnenlands Bestuur schreef recent dat gemeentelijke programmabegrotingen steeds globaler zijn geworden - begrotingen met slechts drie programma's zijn geen uitzondering - waardoor het budgetrecht van de gemeenteraad wordt uitgehold (Verhagen, 2019). Hij constateerde dat de dualisering in dit opzicht 'een fiasco' is gebleken.

\section{Bevindingen: controle door gemeenteraden}

Veel van de controle-instrumenten waarover de gemeenteraad beschikt, zijn primair bedoeld voor informatieverwerving. Dat geldt voor het stellen van vragen, of het nu mondelinge, schriftelijke of technische en onderhandse vragen betreft, voor de passieve en actieve informatieplicht van college en burgemeester, maar ook voor rekenkameronderzoek, het verplichte doelmatigheids- en doeltreffendheidsonderzoek door het college en raadsenquêtes. Al die instrumenten leveren de gemeenteraad informatie op die kan worden gebruikt ten behoeve van zijn controlerende taak.

Het vragenrecht biedt de basis voor veel van de informatieverwerving door de raad. In alle onderzochte gemeenten bestaan afspraken, veelal vastgelegd in het Reglement van orde van de raad, over de wijze waarop raadsleden vragen kunnen stellen aan het college en de wijze waarop deze worden behandeld en beantwoord.

13 Ten behoeve van dit artikel is geen systematische analyse gemaakt, maar wij durven de stelling aan dat elke zichzelf respecterende gemeentelijke rekenkamer(commissie) hier weleens onderzoek naar heeft gedaan. 


\section{Tabel 1 Controle-instrumentarium}

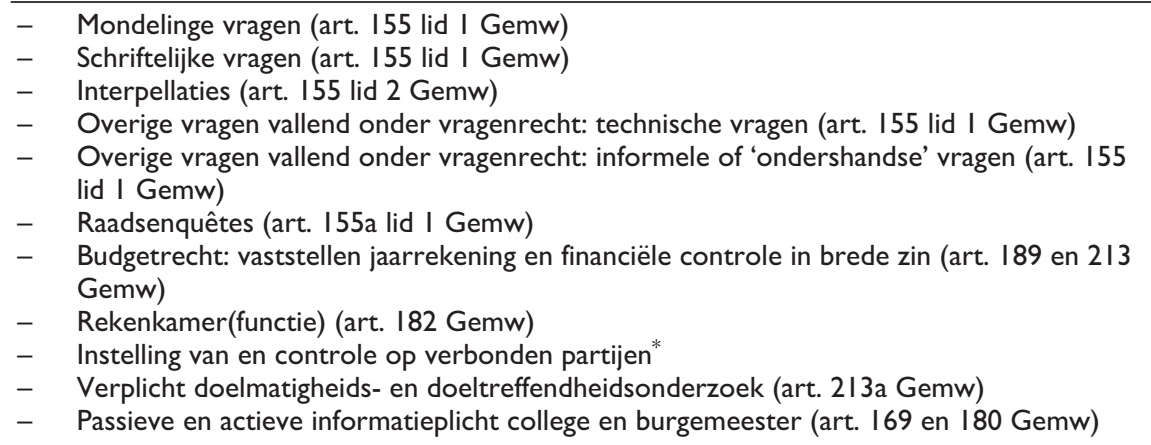

\footnotetext{
* Omdat het onderzoek zich concentreerde op de gang van zaken binnen de gemeente, is op dit aspect van controle weinig ingegaan. Als aan het einde van een interview geïformeerd werd of de respondenten zelf nog iets onder de aandacht wilden brengen, begon menigeen direct over de complexiteit van dit regionale aspect van controle.
}

De verschillen tussen de gemeenten in de mate waarin de diverse instrumenten worden gebruikt, zijn aanzienlijk: in sommige gemeenten worden op jaarbasis vele tientallen mondelinge of schriftelijke vragen gesteld, terwijl dat in andere gemeenten veel minder is. In die laatste gemeenten is het dan vaak gebruikelijk dat veel informatie informeel (onderhands) met de raad wordt gedeeld. Interpellaties vinden in de meeste gemeenten, zeker de kleinere, niet of nauwelijks plaats.

In het overgrote deel van de onderzochte gemeenten is er geen sprake geweest van raadsenquêtes. Daar waar deze in de vorige raadsperiode wel hebben plaatsgevonden, beschouwden raadsleden deze als 'laatste redmiddel' om inzicht te verkrijgen in complexe en soms langslepende kwesties waarover ze tot dat moment onvoldoende waren geïnformeerd. De opbrengsten van deze enquêtes werden, mede in relatie tot de forse inspanningen die ervoor nodig waren, toch overwegend als teleurstellend ervaren.

De jaarrekening is een essentieel controle-instrument van de raad. De daadwerkelijke behandeling van de jaarrekening door de gemeenteraad is in de onderzochte gemeenten een weinig inspirerende gebeurtenis. In de voorbereiding komt de jaarrekening in de auditcommissie aan de orde, vindt de accountantscontrole plaats, en worden door raadsleden technische vragen gesteld, al dan niet in aparte informatiebijeenkomsten. De jaarrekening leidt in het algemeen niet of nauwelijks tot politieke discussie in de raad, en wordt uiteindelijk vaak als een soort hamerstuk vastgesteld.

Als instrument van financiële controle is er in de onderzochte gemeenten weinig discussie over de jaarrekening en de wijze van behandeling. Vastgesteld kan echter worden dat, als spiegelbeeld van de discussies over de sturende werking van de begroting, overal op zijn minst enige onvrede is over de wijze waarop de jaarrekening raadsleden in staat stelt zich een goed beeld te vormen over 'hoe het nu gaat'; het betreft dan de jaarrekening als instrument van politieke controle. In 
alle onderzochte gemeenten hebben de afgelopen jaren initiatieven ter verbetering van de informatie in de jaarrekening plaatsgevonden. Herordenen en herinrichten van de te verstrekken informatie, of simpelweg het uitdunnen van de informatie zijn veelgehoorde initiatieven om de informatie voor raadsleden beter inzichtelijk te maken. Er zijn aanzienlijke verschillen tussen de onderzochte gemeenten in de tijd en energie die hierin worden gestoken. In sommige gemeenten vinden intensieve gesprekken plaats, soms in raadswerkgroepen met ambtelijke ondersteuning, over de kwaliteit van de informatie, het versterken van de mogelijkheden om de informatie meer als sturingsinstrument of als leerinstrument te kunnen benutten, de herinrichting van de P\&C-cyclus en de ontwikkeling en toepassing van nieuwe instrumenten zoals de methode-Duisenberg. ${ }^{14}$ In drie van de door ons onderzochte gemeenten heeft de raad geëxperimenteerd met de methode-Duisenberg, waarbij één of twee raadsleden zich samen, met extra ambtelijke ondersteuning, verdiepen in een specifiek thema of begrotingsprogramma en vervolgens over hun bevindingen verslag uitbrengen aan de hele raad. De beoordeling van de opbrengst van dit experiment is wisselend. De ervaring is dat de methode tot meer bruikbare informatie en beter inzicht in prestaties leidt, maar wel zeer arbeidsintensief is, zowel voor de raadsleden zelf als qua ambtelijke ondersteuning.

In het onderzoek blijken grote verschillen in rol en functioneren van de auditcommissie. In sommige gemeenten is dit een actief platform voor overleg tussen de raad en de accountant en de controller, en soms de rekenkamer, over alles wat met controle, al dan niet financieel, te maken heeft. Veelbesproken onderwerpen zijn de begroting en rekening en de wijze waarop die ingericht zijn. Maar in andere gemeenten gebeurt er veel minder, en een enkele keer functioneert de auditcommissie helemaal niet.

In alle onderzochte gemeenten is een rekenkamer of rekenkamercommissie ingesteld. Desalniettemin kunnen in sommige gemeenten raadsleden in de praktijk nauwelijks over rekenkameronderzoek beschikken, omdat er gemiddeld per jaar één rekenkameronderzoek of minder wordt afgeleverd. In andere gemeenten is dit wat meer: twee tot maximaal vier onderzoeksrapporten per jaar. Voor dat verschil bestaan verschillende oorzaken. Een belangrijke factor is de grootte van het budget, en dat hangt weer in belangrijke mate af van de omvang van de gemeente. Over de meerwaarde van de rekenkamer(commissie)s en hun onderzoeken moet op basis van het onderzoek genuanceerd worden geoordeeld. De aanbevelingen worden in verreweg de meeste gevallen door de raden overgenomen, maar de uitvoering ervan wordt in diverse gemeenten niet (goed) gemonitord. Over de bruikbaarheid van de onderzoeksconclusies en -aanbevelingen zijn de meningen onder raadsleden verdeeld, en in diverse gemeenten zeggen raadsleden zelden of nooit gebruik te maken van de rapporten voor de controle van het bestuur. Ook in gemeenten waar de rekenkamer een wat sterkere aanwezigheid 
kent, zijn de meeste gesprekspartners (raadsleden, griffiers, bestuurders, ambtenaren) van mening dat er op dit punt zeker verbetering mogelijk is.

Verder is geconstateerd dat in negen van de onderzochte tien gemeenten geen artikel 213a-onderzoek wordt gedaan en aan de raad wordt gestuurd. Dit terwijl de Gemeentewet het bestuur hiertoe in het betreffende artikel expliciet verplicht. Deze opvallende constatering kan in zoverre worden genuanceerd, dat aannemelijk is dat er in materiële zin méér dan in formele zin wordt voldaan aan de in artikel 213a Gemeentewet neergelegde verplichting. De colleges sturen namelijk met enige regelmaat informatie aan de raden die betrekking heeft op de doelmatigheid en doeltreffendheid van het beleid, onder meer in zogenaamde raadsinformatiebrieven. Er komt echter niet veel terecht van de in het wetsartikel neergelegde intentie om jaarlijks met raad en rekenkamer de onderzoeksagenda voor doelmatigheids- en doeltreffendheidsonderzoek af te stemmen en over de resultaten daarvan structureel verantwoording aan de raad af te leggen.

Het algemene beeld van de kwaliteit van de informatievoorziening dat uit het onderzoek naar voren komt, is dat gemeenteraadsleden zich zeker niet altijd goed geïnformeerd voelen. Of dat terecht is, kan op grond van dit onderzoek niet zonder meer worden vastgesteld. De kwaliteit van de informatievoorziening - of het nu gaat om de beantwoording van raadsvragen, de inhoud van raadsinformatiebrieven of de inhoud van de jaarrekening - was geen onderwerp van onderzoek. Maar in diverse van de onderzochte gemeenten blijken politieke scheidslijnen tussen coalitie en oppositie van invloed op de vraag of de raadsleden zich goed geïnformeerd voelen. ${ }^{15}$ Verder is de soms ronduit slechte digitale informatievoorziening in veel gemeenten een serieuze handicap voor raadsleden om hun controlerende werk goed te kunnen uitvoeren. In het merendeel van de gemeenten worden applicaties gebruikt die het vergaderproces digitaal ondersteunen en de digitale vergaderstukken toegankelijk maken. In de meeste gemeenten blijkt het echter lastig of onmogelijk om een koppeling te realiseren tussen de vergaderstukken en meer uitgebreide inhoudelijke dossiers, waarmee de besluitvorming en de beleidsgeschiedenis vallen te reconstrueren (Van Keulen e.a., 2019).

Tot slot volgt nog een algemene observatie. Controle behelsde in onze definitie naast informatieverwerving ook beoordeling, namelijk een vergelijking van de feitelijke situatie met de norm c.q. het kader. In het onderzoek is duidelijk gebleken dat die beoordeling vaak niet of slechts impliciet plaatsvindt. Enkel het opvragen van informatie wordt door veel raadsleden beschouwd als het geven van invulling aan hun controlerende taak. Gesteld kan worden dat het controlerende werk vaak niet (of niet zichtbaar) wordt 'afgemaakt'. Dat geldt overigens niet voor de financiële controle, die met de behandeling en vaststelling van de jaarrekening wel een duidelijk, formeel moment van beoordeling kent. Voor de politieke controle is dat

15 Op basis van het onderzoek kunnen niet voor alle onderzochte gemeenten uitspraken hierover worden gedaan, omdat gesproken is met een beperkt aantal raadsleden per gemeente, en soms ook in een groepsgesprek met coalitie- en oppositieraadsleden samen. 
in zekere zin niet altijd mogelijk: wat raadsleden doen met de verkregen informatie, vindt nu eenmaal veelal buiten de spotlights plaats. Maar sommige griffiers en burgemeesters, en ook raadsleden zelf, wijzen erop dat het goed zou zijn als raadsleden hun controle-activiteiten minder ad-hoc aanpakken en de diverse beschikbare instrumenten op meer gestructureerde wijze inzetten, zodat zichtbaar is voor college, collega-raadsleden en zeker ook de buitenwereld dat de informatie wordt gewogen en waar dit toe leidt.

Een laatste en opmerkelijke bevinding betreft de driedeling in verantwoordingsmotieven, zoals die door Bovens e.a. (2008) is geformuleerd: verantwoording ter democratische legitimatie, verantwoording ter bevordering van effectieve tegenmacht en verantwoording ter stimulering van een beter presterende overheid. In de gesprekken met raadsleden bleek dat geen van de respondenten deze driedeling herkende of er, al dan niet bewust, invulling aan gaf. Deze op zichzelf teleurstellende uitkomst is niet voldoende om te constateren dat de driedeling niet relevant is voor de praktijk van verantwoording en controle in het lokaal bestuur. Het zou kunnen dat een andere onderzoeksaanpak tot een ander resultaat had geleid. Maar het is wel een uitkomst die moet worden meegewogen bij het nadenken over nader onderzoek.

\section{Bevindingen: interactie rondom controle en kaderstelling door de raad}

In het onderzoek is uitgebreid aandacht besteed aan de diverse andere actoren in het lokaal bestuur die betrokken zijn bij de processen van kaderstelling en controle door de raad.

De burgemeester is als voorzitter van de gemeenteraad en van het college van $\mathrm{B} \& W$ een sleutelfiguur in het verkeer tussen raad en college. Die dubbelfunctie, die niet is veranderd met de invoering van het dualisme in 2002, brengt een bijzondere verantwoordelijkheid met zich mee voor het verloop van de besluitvorming en de bijbehorende informatiestromen, terug te vinden in artikel 170 lid 1a van de Gemeentewet. Dit artikel staat ook wel bekend als 'de zorgplicht' van de burgemeester. Als voorzitter van de raad speelt de burgemeester bij het gebruik van veel raadsinstrumenten een belangrijke rol. Zo is hij als voorzitter van de raad vaak degene die bepaalt of door raadsleden ingediende mondelinge en schriftelijke vragen worden toegestaan, veelal op advies van de griffier.

De meeste burgemeesters in het onderzoek vinden dat er heel wat moet verbeteren aan de wijze waarop raadsleden hun controlerende werk doen. Een deel van hen constateert dat de raad zich bij zijn controlerende werk geregeld te veel op de details concentreert (een 'klacht' die vaak bij bestuurders wordt gehoord, zo stelde ook Berenschot al vast in de evaluatie van de dualisering (2004: 137), en geeft aan daarop waar mogelijk te corrigeren of bij te sturen. Het onderzoek laat verder zien dat er verschillen bestaan tussen de burgemeesters in de mate waarin zij actief werken aan het (beter) in positie brengen van de raad: de ene burgemeester is daar beduidend meer mee bezig dan de andere. De meest actieve bur- 
gemeesters zeggen dit ook te doen door bij de wethouders aandacht te vragen voor een goede informatievoorziening aan de raad. Een enkeling waagt het hierover soms de strijd aan te gaan in het college, maar erkent tegelijkertijd dat je hiermee voorzichtig moet zijn; je kunt je positie en gezag in het college snel verliezen. De omvang van een gemeente lijkt geen verklarende factor voor de verschillen in opstelling van de burgemeesters. Wat wel een rol speelt, is de politiekbestuurlijke situatie in de gemeente: burgemeesters die met veel politiek 'gedoe' in raad en college te maken hebben, zijn - begrijpelijkerwijs misschien - minder bezig met het versterken van de (kaderstellende en controlerende) rol van de raad, en meer met het voorkomen van politieke spanning en het overeind houden van het college. Het door burgemeesters zelf genoemde streven om hun raad te versterken wordt soms wel, en soms minder herkend door de andere gesprekspartners in dezelfde gemeente. Raadsleden noemen de burgemeester in het algemeen niet spontaan als een bondgenoot in hun controlerende werk. Vastgesteld kan bovendien worden dat de meeste burgemeesters nauwelijks contact hebben met individuele raadsleden, buiten raadsvergaderingen om.

Een belangrijke bondgenoot van de gemeenteraad bij de vervulling van zijn kaderstellende en controlerende taken is de griffier. Alle griffiers in het onderzoek voelen zich verantwoordelijk voor het versterken van de informatiepositie van de raad, maar er zijn aanzienlijke verschillen in de ruimte die zij nemen c.q. krijgen om invloed uit te oefenen op de aangeleverde informatie. De meeste griffies houden ten behoeve van de raad overzichten bij van moties en toezeggingen van het college, en gaan soms ook actief achter toezeggingen aan. In een van de onderzochte gemeenten vindt vooraf systematisch overleg plaats tussen griffie en ambtelijke organisatie over dossiers die eraan komen, waarbij de griffie actief meedenkt en stuurt op timing en inhoud van de voorstellen. Er zijn aanzienlijke verschillen in de wijze waarop en de mate waarin griffiers inhoudelijk betrokken zijn bij de stukkenstroom van college aan raad en de bewaking van de kwaliteit hiervan. Sommige griffiers kijken al vroegtijdig mee met de ambtelijke stukkenstroom richting het college, en kunnen in die fase al eventueel commentaar vanuit het perspectief van raadsondersteuning kenbaar maken. Maar de meeste griffiers komen pas in beeld als de voorstellen reeds geschreven zijn. Sommigen van hen sturen een raadsvoorstel dan weleens terug de ambtelijke organisatie in, met de vraag om verduidelijking of verbetering; in andere gemeenten is dit absoluut niet gebruikelijk. In twee van de onderzochte gemeenten schrijft de griffie bij raadsvoorstellen afkomstig van het college vaak een oplegnotitie of annotatie voor de raadsleden, met achtergrondinformatie en een inhoudelijke duiding van het voorstel. Daar waar dit niet (meer) gebeurt, is dat omdat de raad, of een deel daarvan, geen behoefte heeft aan deze vorm van inhoudelijke ondersteuning: 'Dat kunnen wij zelf wel' of 'Daar zitten wij niet op te wachten'. In een van de onderzochte gemeenten beschikt de griffie over structurele ambtelijke capaciteit om onderzoek te laten uitvoeren ten behoeve van de raad, bijvoorbeeld in de vorm van een second opinion op door het college aangeleverde raadsvoorstellen. 
De meeste gemeenteraadsleden zijn tevreden over het functioneren van de eigen griffier. Dat neemt niet weg dat er binnen gemeenteraden geen algemeen gedeelde opvatting bestaat over de gewenste rol en meerwaarde van de griffie. Sommige raadsleden, met name van kleine (oppositie)fracties, zouden zeker meer ondersteuning kunnen gebruiken, terwijl andere raadsleden in dezelfde gemeente hiervoor geen aanleiding zien. Behalve omvang van de fractie lijkt ook politieke opportuniteit daarbij een rol te spelen: coalitiefracties hebben niet altijd behoefte aan een sterke en strategisch adviserende griffie(r). Daarnaast geven veel raadsleden desgevraagd aan niet goed te weten waar ze eventuele extra ondersteuning voor zouden willen gebruiken. Een veelgehoorde aarzeling is dat meer ondersteuning méér papierwerk betekent, en ook meer vergaderingen en bijeenkomsten. Velen voelen zich in dat opzicht al zwaarbelast. Het is een opvallende constatering dat slechts een enkel raadslid professionele ondersteuning ziet als een manier om de werkbelasting te verlichten en de effectiviteit van hun werk te vergroten.

De genoemde aarzelingen bij raadsleden betekenen niet dat er geen griffiers zijn die de ambitie hebben om de strategische meerwaarde van de griffie te vergroten en de raad als serieuze tegenmacht te positioneren. Een enkele griffier geeft hier al serieus invulling aan. De meesten van hen stuiten echter behalve op onwil bij (een deel van) de raad en het college ook op de grenzen van de beschikbare middelen.

In het onderzoek is ook met wethouders gesproken. ${ }^{16}$ Een belangrijk thema in die gesprekken was de informatievoorziening door het college aan de raad en de wijze waarop de passieve en actieve informatieplicht door hen worden ingevuld. Met name de actieve informatieplicht is een bron van onzekerheid en soms gespannen discussie in veel gemeenten. Het desbetreffende wetsartikel bevat de passage dat de raad 'alle benodigde informatie' moet worden verstrekt. Maar er zijn geen harde criteria om te bepalen of informatie 'nodig' is. De toepassing van de bekende drieslag 'tijdig, juist en volledig' lost dat probleem niet wezenlijk op. Dit leidt ertoe dat sommige bestuurders liever te veel dan te weinig informatie aan de raad verstrekken, met veel informatieve bijeenkomsten en vooral het veelvuldig versturen van raadsinformatiebrieven als gevolg.

Behalve schriftelijke informatie zijn er natuurlijk ook rechtstreekse contacten tussen wethouders en raadsleden. Wat dat betreft zijn coalitiefracties duidelijk in het voordeel: zij hebben begrijpelijkerwijs veel contact met hun eigen wethouder en weten eerder en meer over lopende zaken. In diverse gemeenten schuiven wethouders geregeld of zelfs standaard aan bij de vergadering van de 'eigen' fractie, zij het soms alleen voor een deel van de vergadering. Die constatering is in lijn met de uitkomsten van de Berenschot-evaluatie in 2004, die overigens stelde dat de vanzelfsprekende aanwezigheid bij fractievergaderingen substantieel was afgenomen sinds de dualisering (2004: 114-119). Dit aanschuiven is in zekere zin 
opvallend, omdat er bij de invoering van het dualisme vanuit werd gegaan dat de positionele ontvlechting tussen raad en college gepaard zou gaan met een einde aan de aanwezigheid van wethouders bij 'hun' fractievergaderingen (Denters \& Pröpper, 2002).

Als we breder kijken naar contacten tussen wethouders en de raad en zijn griffier, dan zien we duidelijke verschillen tussen de onderzochte gemeenten in de mate van intensiteit waarin die contacten plaatsvinden. Hierin speelt de schaal van gemeenten een rol: in kleine gemeenten is de afstand letterlijk kleiner, en is het makkelijker om bij de wethouder binnen te lopen. Maar doorslaggevend is toch vooral de cultuur, in de zin van openheid en de kwaliteit van de onderlinge relaties tussen de hoofdrolspelers. Sommige wethouders lopen geregeld bij de griffie langs om te overleggen over de inhoud en procedurele afstemming van raadsvoorstellen. In een van de onderzochte (grote) gemeenten voeren raadsadviseurs van de griffie structureel overleg met bestuursadviseurs van de wethouders over de timing en wijze van aanlevering van raadsvoorstellen, en de wijze van informatievoorziening in bredere zin.

Een van de interessante maar niet gemakkelijk te duiden bevindingen van het onderzoek is dat de wijze waarop het college en de individuele portefeuillehouders de raad informeren per gemeente een zeker patroon lijkt te vertonen. Dat zou je als 'cultuur' kunnen omschrijven. De mate van openheid en ruimhartigheid waarmee een bestuurder, en dus vaak ook de ambtelijke organisatie, bereid is de raad van informatie te voorzien, blijkt in bijna alle gesprekken een relevante factor te zijn voor zowel de kwaliteit van de informatievoorziening als voor de tevredenheid van raadsleden over de invulling van hun controlerende rol. Dit wordt mooi verbeeld door de wethouder die stelt: 'In onze verhoudingen werkt het zo dat het college een verzoek om een second opinion gewoon uitvoert als de raad daar om vraagt.' Het was een typerende constatering in een gemeente waar zelden of nooit op het scherpst van de snede over informatievoorziening aan de raad hoeft te worden gesproken. Tegelijkertijd was het een opmerking die in diverse andere onderzochte gemeenten nooit gemaakt had kunnen worden; daar zou een dergelijk verzoek smoren in het (wederzijds) wantrouwen tussen (een deel van) de raad en het college en in de politieke tegenstellingen binnen de raad.

Dit cultuurelement speelt ook een cruciale rol bij de vraag of er in de gemeente sprake is van een goed functionerend driehoeksoverleg tussen burgemeester, griffier en gemeentesecretaris. Daar waar sprake is van een goed functionerende driehoek, wordt vaak melding gemaakt van een open cultuur met veel onderling vertrouwen tussen raad en griffie enerzijds en bestuur en ambtelijke organisatie anderzijds. In die gemeenten is er in de driehoek aandacht voor de positionering van de raad, en in het bijzonder de kwaliteit van de informatievoorziening aan de raad. Dat werkt echter zeker niet in alle gemeenten zo: in de helft van de door ons onderzochte gemeenten vindt in de praktijk weinig of geen driehoeksoverleg plaats. Het succes van het driehoeksoverleg is, zoals eerder ook vastgesteld door Riezebos en Verhoeff (2014), sterk afhankelijk van de goede wil en inzet van drie personen binnen een gemeentelijke organisatie. 
Een laatste, uiterst belangrijke vorm van interactie rondom de kaderstelling en controle door de raad betreft de verhoudingen binnen de raad. Eerder stelden we al vast dat raadsleden van oppositiefracties zich vaak minder goed geïnformeerd voelen dan die van coalitiefracties. Dat wethouders meer contact hebben met hun eigen fractie, is daarbij een factor. Maar belangrijker zijn misschien wel de verhoudingen tussen coalitiefracties en oppositiefracties binnen de raad. In het onderzoek stelden we vast dat in alle gemeenten coalitieoverleg plaatsvindt tussen de coalitiefracties, in sterk wisselende intensiteit. Het overleg is bedoeld om de in coalitieverband gemaakte afspraken te bewaken en ervoor te zorgen dat zich geen onverwachte gebeurtenissen ('bedrijfsongevallen') voordoen tijdens belangrijke besluitvormingsprocessen. De vraag is wat deze blokvorming betekent voor de manier waarop de raad zijn controlerende rol kan vervullen. Denters e.a. (2000) concludeerden in hun vooronderzoek voor de Commissie-Elzinga dat vóór de invoering van het dualisme de wethouder via het directe contact met de fractie een belangrijk stempel drukte op de besluitvorming binnen zijn fractie (Denters e.a., 2000: 218). Ook zagen zij dat het zwaartepunt van de belangenafweging in gemeenten vooral bij de niet-openbare vergaderingen van het college en de raadsfracties lag en dat met name bij controversiële beslissingen het verloop van fractievergaderingen van de collegefracties dus medebepalend was voor de uitkomst van de besluitvorming (Denters e.a., 2000: 222). Denters en anderen hadden het over besluitvorming, en niet expliciet over controle van het college en de portefeuillehouders, maar het ligt voor de hand dat hetzelfde kanaal en dezelfde invloed niet alleen werden gebruikt om steun te verkrijgen voor beleidsvoorstellen, maar ook om te voorkomen dat in de openbaarheid al te scherpe controle werd uitgeoefend. Het lijkt erop dat dit na de dualisering over de volle breedte van het lokaal bestuur wat minder is geworden - Berenschot stelde in 2004 vast dat wethouders vaker in raadscommissies verantwoording aflegden dan voor de dualisering, en minder vaak dan voorheen in hun eigen fracties (Berenschot, 2004: 133-136) -, maar uit ons onderzoek blijkt dat die band tussen wethouder en fractie geenszins is doorgeknipt, en dus naar alle waarschijnlijkheid ook nu nog wordt gebruikt voor controle binnenskamers in plaats van in de openbaarheid. In ons onderzoek hebben we hier zeker aanwijzingen voor gevonden, maar dit is een gevoelig en in veel gemeenteraden moeilijk bespreekbaar onderwerp. ${ }^{17}$

\section{Conclusie en discussie}

Het onderzoek waarover in deze bijdrage verslag is gedaan, heeft veel empirische kennis opgeleverd over de wijze waarop gemeenteraden de diverse instrumenten van kaderstelling en controle gebruiken, en over de betrokkenheid daarbij van andere hoofdrolspelers zoals burgemeester, griffier, wethouders en ambtelijke organisatie. Lastiger bleek het om de onderzoeksvraag naar de wenselijkheid van aanpassing van het instrumentarium op bevredigende wijze te beantwoorden. De respondenten, inclusief de raadsleden, zagen geen aanleiding om het instrumen- 
tarium uit te breiden. Maar de onderliggende vraag naar de effectiviteit van de huidige praktijk van kaderstelling en controle door gemeenteraden kon op basis van dit onderzoek niet worden beantwoord. Dit is zonder meer een opdracht voor vervolgonderzoek. Het toetsingskader voor verantwoordingsarrangementen van Bovens e.a. (2008) leidde in eerste instantie echter niet tot herkenning bij raadsleden. Wij zien de motieven voor controle en verantwoording van Bovens e.a. wel terug in de wereld van gemeentelijke rekenkamers, waar soms onderscheid wordt gemaakt tussen onderzoeken bedoeld om 'af te rekenen' en onderzoeken bedoeld om van te leren.

Het onderzoek laat zien dat diverse instrumenten door gemeenteraden niet of weinig worden gebruikt. Zonder goed beoordelingskader kan niet zonder meer worden vastgesteld of dat negatieve gevolgen heeft voor de effectiviteit van de kaderstelling en controle. Wel is duidelijk dat het niet-gebruiken van instrumenten er soms toe leidt dat een raad over minder (goede) informatie en ondersteuning beschikt dan mogelijk zou zijn, bijvoorbeeld als gaat om een rekenkamer(commissie), fractieondersteuning of een goed toegeruste griffie. Als van het gebruik van zo'n instrument wordt afgezien uit politieke of machtsoverwegingen binnen de raad - en die situaties zijn zeker aan de orde gekomen in het onderzoek -, dan kan worden vastgesteld dat daarmee afbreuk wordt gedaan aan de doelstelling van de dualisering om bestuur en controle daarop duidelijker te scheiden en de controlerende rol van de raad als geheel te versterken.

Op één punt biedt het onderzoek wel concreet aanleiding tot heroverweging van het instrumentarium, en dat betreft het instrument van de programmabegroting en de bijbehorende (programma)rekening. Ondanks een recente ingreep met verplichte (beleids)indicatoren bestaat in alle onderzochte gemeenteraden ontevredenheid over de mogelijkheden die de begroting biedt om daadwerkelijk te sturen en controleren, wat leidt tot steeds terugkerende discussies over een andere programma-indeling en andere indicatoren, zonder dat de twijfel wordt verholpen. Ook uit ander onderzoek, onder meer door lokale rekenkamers, blijkt dat de programmabegroting tekortschiet als instrument voor kaderstelling en controle (o.a. Rekenkamer Maastricht, 2012). Dit instrument moet zeker onderwerp zijn van heroverweging.

Terug naar de onderliggende vraag hoe het is gesteld met de effectiviteit van kaderstelling en controle. Het onderzoek heeft laten zien dat in de onderzochte gemeenten en gemeenteraden geen sprake is van een (gedeelde) visie op controle en de relatie met kaderstelling. ${ }^{18}$ De vraag wat de controlerende taak eigenlijk behelst, en waartoe je als raad en als raadslid eigenlijk controleert, wordt in de praktijk niet gesteld of besproken. Dit is des te vervelender, omdat de wet op dit

18 Deze constatering staat op het eerste gezicht op gespannen voet met de al jarenlang, vooral door gemeentesecretarissen uitgedragen boodschap dat in het lokaal bestuur 'controle op controle wordt gestapeld', hetgeen zou leiden tot een welhaast ondragelijke controlelast (Deloitte \& VGS, 2011). Toch hoeven wat ons betreft beide constateringen niet met elkaar in tegenspraak te zijn; immers, wat ontbreekt is lijn in de controle, en een doelgerichte inzet van instrumenten. 
punt weinig duidelijkheid biedt. Met de dualisering is de controlerende taak van de raad expliciet onderscheiden - naast kaderstelling en volksvertegenwoordiging -, maar noch in de Gemeentewet noch in de Wet dualisering en de bijbehorende memorie van toelichting is omschreven waarop de controle betrekking heeft of waartoe deze moet dienen, de financiële controle (aan de hand van de jaarrekening) uitgezonderd. Het betekent dat raadsleden weinig houvast wordt geboden bij de invulling van hun controlerende rol, terwijl zij zich er tegelijkertijd van bewust zijn - zo weten we uit eerder onderzoek van onder meer De Groot (2009) - dat het een belangrijke taak is die versterking behoeft. Dat is een zorgwekkende constatering.

Wij stelden vast - en werden daarop ook door diverse betrokkenen gewezen - dat raadsleden zich bij de invulling van hun controlerende rol veelal beperken tot het vragen van informatie, en niet, of niet expliciet en zichtbaar, toekomen aan de beoordeling ervan. Dat leidde tot de conclusie dat zij hun controlerende werk daarmee in zekere zin vaak niet 'afmaken'. Deze conclusie roept de vraag op of misschien gekozen is voor een te strikte definitie van controle, namelijk de combinatie van informatieverzameling over de feitelijke situatie met expliciete beoordeling aan de hand van de norm(en). Moet het vragen van informatie in de openbaarheid misschien ook als (een vorm van) controle worden gezien? Niet voor niets is informatievoorziening onverbrekelijk verbonden met controle en verantwoording. Openbare informatie over het optreden van het bestuur en de gevolgen daarvan stelt iedereen, zowel raadsleden als de burgers die zij vertegenwoordigen, in staat om de vergelijking met een zelfgekozen norm of kader te maken. Anticipatie daarop betekent bovendien dat het bestuur zich bekeken ofwel gecontroleerd voelt, wat tot ander optreden leidt dan zonder de openbaarheid. In die zin is het enkel vragen van informatie niet zonder consequenties. Het verdient kortom aanbeveling om te overwegen de definitie van controle meer aan te laten sluiten bij de praktijk in het (lokaal) bestuur.

De beelden van de controlepraktijk, zo bleek verder uit het onderzoek, kunnen sterk uiteenlopen, ook binnen één gemeente. Het feit dat de controle plaatsvindt in een politiek-bestuurlijke omgeving, betekent bovendien dat er geen eenduidige normen of kaders bestaan aan de hand waarvan wordt gecontroleerd. Immers, in een politiek-bestuurlijke omgeving is direct al omstreden wie de norm stelt, en wat die norm dan is. In de meeste gemeenten bleken in dit opzicht grote - natuurlijk niet onverwachte - verschillen te bestaan tussen coalitie en oppositie. Coalitiefracties baseren zich, net als het college, op afspraken in het coalitieakkoord, op vastgesteld beleid en de doelstellingen in de programmabegroting; die vormen voor hen de kaders. Raadsleden van oppositiepartijen onderschrijven echter zeker niet altijd de afspraken uit het coalitieakkoord en de daaruit voortkomende beleidsvoorstellen van het college, en beoordelen het beleid en de uitvoering ervan deels ook op hun eigen normen. Daarvoor is niet altijd begrip bij coalitiefracties, college en ambtelijke organisatie.

We stuiten hier ook op de vraag in welke mate goede kaderstelling en controle consensus en samenwerking binnen de raad vereisen. Recentelijk hebben diverse 
auteurs aandacht gevraagd voor de verschillende functies of krachten van de raad (Schulz e.a., 2018; Van Ostaaijen, 2018). Enerzijds is de raad een politiek orgaan, waar ruimte moet zijn voor politieke verschillen en de strijd daartussen; dat is de divergerende kracht in de raad. Anderzijds is de raad ook een bestuursorgaan, dat binnen het gemeentebestuur zijn bestuurlijke rol vervult, en in die rol in een zekere gezamenlijkheid moet opereren; dat is de convergerende kracht in de raad. Wil de raad zijn rol als kadersteller en controleur van het college goed vervullen, dan is een zekere mate van samenwerking of eensgezindheid nodig. In de praktijk is dat vooral relevant wanneer het gaat om een goede informatievoorziening aan de raad en de ondersteuning van de raad; dat is relevant voor alle raadsleden, zowel van coalitie als oppositie. Vanuit dit perspectief is het problematisch dat er op lokaal niveau geen erkende probleemeigenaar van 'goede controle' en 'goede informatievoorziening' is (zie Castenmiller e.a., 2013; Castenmiller \& Peters, 2018; Peters \& Castenmiller, 2019). De burgemeester als voorzitter van de raad lijkt, samen met de griffier, de eerst aangewezene voor deze regiefunctie, maar het onderzoek laat zien dat burgemeesters deze rol niet altijd even serieus invullen. De divergerende kracht in de raad leidt er bovendien toe dat de coalitiefracties het belang van goede informatievoorziening en goede ondersteuning nog weleens ondergeschikt willen maken aan het politieke belang van het steunen van het college. Dat leidt er dan bijvoorbeeld toe dat het presidium of seniorenoverleg $^{19}$ zich vooral tot praktische afspraken beperkt en wegblijft van inhoudelijke sturing op controle en de kwaliteit van informatievoorziening. Vastgesteld kan worden dat veel gemeenteraden op dit punt leiderschap ontberen.

Er blijken aanzienlijke verschillen te bestaan tussen gemeenten in de mate van tevredenheid over de informatievoorziening aan de raad en daarmee de mogelijkheden tot betekenisvolle controle. Het onderzoek toont een enkele witte raaf tussen de onderzochte gemeenten, waar raad, college en ambtelijke organisatie constructief samenwerken en waar het bestuur oog blijkt te hebben voor het belang van een goede informatievoorziening aan de hele raad. In een dergelijke gemeente speelt vaak ook de driehoek van burgemeester, griffier en gemeentesecretaris een constructieve rol bij het in positie brengen van de raad, en slagen raadsleden er geregeld in om over de grenzen van coalitie en oppositie heen elkaar de ruimte te geven en samen te werken. In het onderzoek is onvoldoende duidelijk geworden hoe dergelijke verschillen in bestuurscultuur (zijn) ontstaan en hoe die in stand blijven. Het heeft iets te maken met kwaliteiten van genoemde sleutelpersonen, met de al dan niet gepolariseerde verhoudingen in de raad, en met specifieke maatschappelijke uitdagingen (of juist het ontbreken daarvan). Maar deze opsomming is niet compleet, en bovendien blijft met het benoemen van dergelijke factoren onduidelijk welke nu bepalend zijn en welke juist daaruit volgen. Ook hier is nader onderzoek hard nodig, juist voor al die burgemeesters, griffiers en natuurlijk gemeenteraden die zoeken naar versterking van de positie van de raad in dit opzicht. 


\section{Literatuur}

Adviescommissie Vernieuwing van de begroting en verantwoording van gemeenten, Eindrapport, Den Haag: 2014.

B\&A Groep, Staat van het Dualisme, in opdracht van het ministerie van BZK, Den Haag: 2008.

Bakker, N., P.G. Castenmiller \& B. Smallenbroek, De alledaagse praktijk van het lokaal bestuur, Staatscommissie Dualisme en Lokale Democratie (onderzoeksbijlagen), Den Haag: 2000.

Berenschot, Evaluatie van de Wet dualisering gemeentebestuur, Utrecht: 2004.

Boogers, M.J.G.J.A., P.J. Klok, S.A.H. Denters \& M.P.T. Sanders, Effecten van regionaal bestuur voor gemeenten. Bestuursstructuur, samenwerkingsrelaties, democratische kwaliteit en bestuurlijke effectiviteit, Enschede: 2016.

Boogers, M.J.G.J.A. \& G.H. Reussing, Decentralisatie, schaalvergroting en lokale democratie. Samenvattend onderzoek naar gevolgen voor rollen en posities van lokale bestuurders en naar gevolgen voor bestuurskracht en democratie, Enschede: 2018.

Bovens, M.A.P., T. Schillemans \& P. 't Hart, 'Does public accountability work? An assessment tool', Public Administration, 2008/1, p. 225-242.

Castenmiller, P.G., M.J.E.M. van Dam \& C.E. Peters, ... Geven de raad alle inlichtingen ... Een onderzoek naar informatievoorziening aan de gemeenteraad, onderzoek in opdracht van het ministerie van BZK, Den Haag: 2013.

Castenmiller, P.G. \& C.E. Peters, 'Wel aan het hoofd, maar niet de baas. De verhouding tussen raad en college in de praktijk', H. Vollaard, G. Boogaard, J.T.J. van den Berg \& M.J. Cohen (eds.), De Gemeenteraad. Ontstaan en ontwikkeling van de lokale democratie. Amsterdam: 2018, p. 207-223.

Commissie-Ollongren (VNG Denktank), Maatwerkdemocratie. Naar een krachtiger, trefzekere gemeenteraad 2020 als kruispunt in de lokale democratie, jaarbericht 2016, Den Haag: 2016.

Commissie-Van de Donk (Commissie toekomstgericht lokaal bestuur), Op weg naar meervoudige democratie. Den Haag: 2016.

Daadkracht, Nationaal Raadsledenonderzoek. Trendonderzoek naar de tijdsbesteding en werkzaamheden van gemeenteraadsleden, Nijmegen: 2014.

Daadkracht, Nationaal Raadsledenonderzoek. Vijfde Trendonderzoek naar de tijdsbesteding en werkzaamheden van gemeenteraadsleden, Nijmegen: 2017.

Deloitte \& Vereniging van Gemeentesecretarissen (VGS), Met lef en durf de controletoren aanpakken... Onderzoek naar de ervaren controle- en verantwoordingsdruk binnen 13 gemeenten, Den Haag: 2011.

Denters, S.A.H., 'Controle en verantwoording in een veranderend lokaal bestuur', Bestuurswetenschappen, 2016/1, p. 37-54.

Denters, S.A.H., P.J. Klok \& A. Kranenburg, ‘Greep op het ongrijpbare? Een onderzoek naar nieuwe vormen van controle en verantwoording in een samenwerkend lokaal bestuur', Bestuurswetenschappen, 2017/4, p. 25-44.

Denters, S.A.H., H. van der Kolk, E. Birkenhäger, H.M. de Jong, M. Loots \& R. Noppe, 'Aan het hoofd der gemeente staat...', Rapport van de Staatscommissie Dualisme en Lokale Democratie, deel II, onderzoeksbijlage, Alphen aan den Rijn: 2000, p. 143-227.

Denters, S.A.H. \& I.M.A.M. Pröpper, Naar een politiek profiel voor de gemeenteraad. Eindrapportage Project duale gemeenten, Den Haag: 2002.

Enthoven, G.M.W., Hoe vertellen we het de Kamer? Een empirisch onderzoek naar de informatierelatie tussen regering en parlement, proefschrift Universiteit van Tilburg, Delft: 2011. 
Groot, M.S. de, Democratic effects of institutional reform in local government. The case of the Dutch Local Government Act 2002 , proefschrift Universiteit Twente, Enschede: 2009.

Groot, M.S. de, S.A.H. Denters \& P.J. Klok, 'Strengthening the councillor as a representative and scrutinizer. The effects of institutional change on councillors' role orientations in the Netherlands', Local Government Studies, 2010/3, p. 401-423.

Hessels, J.W.M.M.J., Raad zonder raadgevers. Ambtelijke bijstand en fractieondersteuning na invoering van de Wet dualisering gemeentebestuur, proefschrift Radboud Universiteit Nijmegen, Deventer: 2018.

Keulen, I. van, I. Korthagen \& P. Diederen, Griffiers en digitalisering. Naar een sterkere lokale democratie, Rathenau Instituut, Den Haag: 2019.

Nederlandse Vereniging voor Raadsleden, Raad \& Regionale Samenwerking 2017. Landelijk Raadsledenonderzoek over grip en controle op regionale samenwerking, gemeenschappelijke taken en herindeling, Den Haag: 2017.

Ostaaijen, J.J.C. van, Hard naar het college, zacht naar de samenleving. Op zoek naar een nieuwe verbindende rol van de gemeenteraad, essay, Tilburg: 2016.

Ostaaijen, J.J.C. van, 'Reflectie. Een bestuurlijk rollenspel voor de raad', Nederlandse Vereniging voor raadsleden, De bestuurlijke rol van de raad, Den Haag: 2018, p. 37-38.

Peters, C.E. \& P.G. Castenmiller, Om de controle door de raad. Een onderzoek naar de toepassing van het raadsinstrumentarium voor controle en kaderstelling in de gemeentelijke praktijk, in opdracht van het ministerie van BZK, Den Haag: 2019.

Raad voor het openbaar bestuur, Wisselwerking, Naar een betere wisselwerking tussen gemeenteraden en de bovengemeentelijke samenwerking, Den Haag: 2015.

Rekenkamer Breda, Verbonden partijen en de rol van de raad. Een onderzoek naar de informatievoorziening, sturing en beheersing ten aanzien van verbonden partijen in Breda, Breda: 2015.

Rekenkamer Den Haag, Moeite met afstand, Den Haag: 2016.

Rekenkamer Maastricht, Quick scan programmabegroting 2012, Maastricht: 2012.

Rekenkamers Rijk van Nijmegen, Grip krijgen op Veilig Thuis, Nijmegen: 2017.

Riezebos, K. \& C. Verhoeff, Burgemeester en griffier. Een vitale relatie, Amersfoort: 2014.

Schram, J., M.J.W. van Twist \& M.A. van der Steen, Raad en hulptroepen. Hefbomen ter versterking van de controlerende taak van de gemeenteraad, Den Haag: 2017.

Schulz, J.M., P.H.A. Frissen \& J. Schram, Gemeenteraden positioneren. Van professionaliseren naar politiseren, Den Haag: 2018.

Staatscommissie-Elzinga, Dualisme en Lokale Democratie, eindrapport, Den Haag/Alphen aan den Rijn: 2000.

Verhagen, J., 'Raden zitten met de brokken', Binnenlands Bestuur, 2019/23, p. 43.

VNG Realisatie, Raadsleden in de informatiesamenleving, Den Haag: 2019.

Woude, W. van der, Financiële controle in het gemeenterecht. Een juridisch onderzoek naar de 'dualisering' van de financiële functie, Groningen: 2011. 